\title{
ORGANINIO DELYRO HIPODIAGNOSTIKA: DIAGNOSTIKOS PERSPEKTYVOS LIETUVOJE
}

\author{
Džiugilè Kersnauskaitė ${ }^{1}$, Rusnė Kirtiklytė ${ }^{1}$, Petras Navickas ${ }^{2}$, \\ Pranas Šerpytis ${ }^{2,3}$, Alvydas Navickas ${ }^{4}$ \\ ${ }^{1}$ Vilniaus universiteto Medicinos fakultetas, ${ }^{2}$ Vilniaus universiteto Medicinos fakulteto \\ Klinikinès medicinos instituto Širdies ir kraujagyslių klinika, ${ }^{3}$ Vilniaus universiteto ligonine \\ Santaros klinikos, Skubios medicinos centras, ${ }^{4}$ Vilniaus universiteto Medicinos fakulteto \\ Klinikines medicinos instituto Psichiatrijos klinika
}

Raktažodžiai: delyras, diagnostika, kognityviniai sutrikimai, vertinimo skalès ir metodai.

\section{Santrauka}

Lietuvoje stebima delyro hipodiagnostikos problema, kurią aiškinti būtų galima bendrosios delyro diagnozavimo taktikos, kurią galètų taikyti ịvairių specialybių gydytojai, nebuvimu. Yra nemažai standartizuotų diagnostikos ir atrankos skalių, kurios naudojamos nustatant delyro diagnozę.

Tyrimo tikslas. Išanalizuoti validuotus delyro atrankos ir diagnostikos metodus, plačiausiai taikomus klinikinèje praktikoje.

Tyrimo metodika. Atlikta 11 delyro atrankos ir diagnostikos metodų apžvalga; atrinkti metodai lyginti vieni su kitais pagal skalès paskirtį, jautrumą, specifiškumą, vertintoją, vertinimo trukmę ir skalëje vertinamus parametrus. Rezultatai. Iš 11 atrinktų skalių daugiausiai informacijos radome apie NEECHAM (95-97,2\% jautrumas ir 78$82,8 \%$ specifiškumas), Nu-DESC (85,7\% ir $86,8 \%)$ ir CAM (46-100\% ir 63-100\%) metodus. Intensyviosios terapijos pacientams vertinti tinkami penki iš aprašytų metodų: NEECHAM, ICDSC, CAM, CTD ir DDS. Iš jų dažniausiai naudojamos NEECHAM ir CAM (CAM-ICU modifikacija) bei ICDSC. Senyvo amžiaus pacientams labiausiai tinkamos CAM ir Nu-DESC skalès. Dauguma skalių vertina dèmesingumą, orientaciją, sąmonès pokyčius, kalbejjimo ir judesių tikslingumą. Pakartotinis vertinimas reikalingas Nu-DESC, DOSS ir ICDSC metodams. Dauguma skalių, išskyrus ICDSC ir Nu-DESC, neaptinka hipoaktyvios delyro formos.

Išvados. Lietuvoje stebima delyro hipodiagnostikos problema, kurią spręsti būtų galima pasitelkiant validuotas delyro stebėsenos ir diagnostikos skales. Intensyviojoje terapijoje patikimiausios delyro vertinimo skalès yra CAM-ICU, ICDSC ir DDS. Senyvo amžiaus pacientams patartina taikyti CAM ir Nu-DESC metodus bei IQCODE klausimyną. Hipoaktyvaus delyro vertinimui geriausiai tinka ICDSC bei Nu-DESC metodai. Vis dèlto, esant delyro atrankos ir diagnostikos skalių ịvairovei, išlieka poreikis trumpos, greitai ir paprastai pritaikomos, aukšto jautrumo ir specifiškumo suvienodintos vertinimo skalès, tinkamos įvertinti ne tik delyro faktą, bet ir jo subtipą.

\section{Ivadas}

Delyras yra kompleksinis neuropsichiatrinis sindromas, dažniausiai diagnozuojamas vyresniems pacientams, bet galintis pasireikšti įvairiame amžiuje [1]. Tai ūmi būklè, charakterizuojama pakitusiu sąmonès lygiu, dezorientacija, negebejimu sutelkti dèmesio ir kitais kognityviniais sutrikimais, kurie siejami su blogesne prognoze, ilgesne hospitalizacijos trukme, didesniu mirtingumu bei išaugusiais sveikatos priežiūros kaštais $[2,3]$. Nors delyro sindromas gali būti grị̌tamojo pobūdžio, jo išsivystymas pacientams dažniau susijęs su ilgalaike kognityvine disfunkcija [4].

Naujausi moksliniai tyrimai ịrodè, kad delyro sindromas pacientams diagnozuojamas daug rečiau, nei iš tikrujų pasireiškia $[1,5,6]$. Lietuvoje stebima ryški delyro hipodiagnostikos problema: anot $2017 \mathrm{~m}$. atlikto tyrimo, Lietuvoje delyro nustatymo dažnis siekia tik 1,8 proc., [7] kai kitose šalyse šis dažnis siekia 8-31procento [8,9]. Šị skirtumą galima aiškinti tuo, jog kitaip nei užsienyje, Lietuvos gydymo įstaigų klinikineje praktikoje nenaudojamos validuotos delyro aptikimo ir diagnostikos skalès. Jeigu pacientui stebima sutrikusi sąmonès būklè, neadekvatus elgesys ir ryškus sumišimas, kviečiamas gydytojas psichiatras, kuris turi nustatyti ir doku- 
mentuoti delyrą. Tokia sistema (skyriaus personalas, dažnai net ir gydytojai (ne psichiatrai) delyro nevertina, aptinka tik labai ryškiai pasireiškusį delyrą. Ne tokią aiškią simptomatiką turintis delyras, pavyzdžiui, hipoaktyvi jo forma, lieka nediagnozuota.

Pirmą kartą standartizuoti delyro diagnostikos kriterijai buvo aprašyti 1980 metais trečiajame psichikos sutrikimu diagnostikos ir statistikos vadovo leidime (DSM-III) (angl. Diagnostic and statistical manual of mental disorders) [10]. Nuo to laiko delyro kriterijai atnaujinami, kuriamos standartizuotos skalès, padedančios kuo anksčiau, efektyviau ir tiksliau nustatyti delyro diagnozę klinikinejje praktikoje.

Standartizuotų skalių naudojimas veiksmingai didina tikimybę diagnozuoti delyrą bei tinkamai interpretuoti ir stebèti delyro simptomus: paciento sąmoningumo, koncentracijos, kognityvinius sutrikimus [11]. Delyro gydymo sẻkmei svarbiausia diagnozuoti pirminę būklę sukèlusią priežastị, o laiku nediagnozavus delyro, ši priežastis gali likti nežinoma ir negydoma, bloginanti gydymo prognozę. Standartizuotu delyro diagnostikos skalių naudojimas rutininejje praktikoje yra svarbus ankstyvai delyro diagnostikai, pirminès priežasties gydymui bei simptomų stebėsenai ir gali efektyviai prisidèti prie ilgalaikių delyro pasekmių mažinimo. Tad kyla klausimas, kokias diagnostikos priemones būtų galima taikyti mūsų šalies ligoninèse, ir kurios iš jų yra labiausiai perspektyvios.

Tyrimo tikslas - apžvelgti standartizuotas delyro aptikimo ir diagnostikos skales, plačiausiai naudojamas klinikinèje praktikoje, ir palyginti jas tarpusavyje.

\section{Tyrimo medžiaga ir metodai}

Analizavome delyro diagnostikai ir atrankai skirtas skales. Ieškojome straipsnių PubMed sistemoje, ịvairiai kombinuodami raktinius žodžius: delirium, screening, confusion assessment, rating scale, incidence, etiology, risk factors. Pasirinkta 11 standartizuotų klinikinejje praktikoje naudojamų skalių. I tyrimą neįtrauktos skalès, labiau pritaikomos delyro sunkumui nustatyti, o ne jam aptikti. Atrinktus metodus lyginome pagal šiuos parametrus: skales paskirtis, jautrumas, specifiškumas, vertintojas, vertinimo trukmè, vertinami parametrai. Glausta delyro vertinimo metodų apžvalga pateikiama 1 lentelèje.

\section{Tyrimo rezultatai}

Tyrimo metu atrinktos pagrindinès delyro atrankos ir diagnostikos skalès pateikiamos 1 lentelèje.

Pateikiame delyro atrankos ir diagnostikos skalių pritaikymo ir naudojimo platesni paaiškinimą.

NEECHAM sumišimo skale (angl. The Neelon and Champage confusion scale). Ši atrankinè skalè skirta paciento kognityvinių funkcijų, elgesio ir fiziologinių parametrų vertinimui. Skalè aptinka delyrą ( $<25$ balų), gali preliminariai ìvertinti jo sunkumą, nustato delyro išsivystymo riziką. NEECHAM skalè pritaikyta slaugytojoms, dirbančioms slaugymo namuose, stacionare ir IT skyriuose (tinka neintubuotiems pacientams) $[12,13]$.

Slaugos delyro atrankinè skalè Nu-DESC (angl. Nursing delirium screening scale)). Skalès parametrai vertinami 3 kartus per parą, o galutinis balas gaunamas apskaičiuojant paros vidutinę vertę ( $\geq 2$ balų indikuoja delyrą). Nu-DESC skalès taikymo metodas sukurtas taip, jog slaugytojos pacientą gali ịvertinti ịprastoje medicinos praktikoje $[14,15]$.

Delyro stebèjimo atrankos skalè DOSS (angl. Delirium observation screening scale). Ši skalè, kaip ir Nu-DESC, pritaikyta naudoti ịprastineje medicinos praktikoje, o vertinimą atlieka slaugytojos. DOSS susideda iš 25 (sutrumpintame variante - iš 13) parametrų, kurie vertinami „yra“ arba „nèra“. Skalès modelis reikalauja, jog pacientas būtų vertinamas kiekvieną slaugytojų darbo pamainą (laikoma, jog per parą pasikeičia 3 pamainos, todèl pacientas turi būti ịvertintas 3 kartus, o galutinis balų skaičius gaunamas apskaičiuojant visos paros vidutinę vertę). Jei pacientas surenka 3 ir daugiau balų, jam įtariamas delyras $[16,17]$.

Intensyviosios terapijos delyro stebèsenos kontrolinis sarašas ICDSC (angl. Intensive care delirium screening checklist). Tai klausimynas, kurị gali taikyti bet kuris intensyviosios terapijos personalo darbuotojas (ne tik gydytojai ar slaugytojos), pasitelkdami Richmond'o sujaudinimo-sedacijos skalę RASS (angl. Richmond agitation-sedation scale). RASS tinka ir ventiliuojamiems, ir savarankiškai kvèpuojantiems pacientams, seduotiems ir neseduotiems [18]. Taikant RASS, galima ịvertinti hiperaktyvų ir hipoaktyvų delyrą [13]. Kiekvienas parametras vertinamas atsižvelgiant ị paciento būklę per pastarąsias 24 valandas. Mažesnis balų skaičius nurodo subsindrominį delyrą, o tai leidžia aktyviau stebėti pacientą [12].

Pediatrine anestezijos ir skubiosios pagalbos delyro vertinimo skale PAED (angl. Pediatric anesthesia emergence delirium scale). Ši skalè buvo sukurta įvertinti vaikų delyrą skubiosios pagalbos skyriuose ir bundant po bendrosios anestezijos, Surinkus $\geq 10$ taškų, diagnozuojamas delyras [19]. Duomenys apie šią skalę negausūs ir ganètinai seni.

Universalus demesingumo vertinimas GAR (angl. Global attentiveness rating). Šis metodas tai pokalbis (interviu), pagrịstas bendrojo pobūdžio klausimais ir paciento atsakymais. Po mažiausiai 2 minutes trunkančio pokalbio su pacientu, gydytojas turi atsakyti sau ị klausimą, kaip gerai pacientas palaike pokalbị, ir pagal tai ịvertinti galimą delyro vystymąsi. Metodo vertinimas subjektyvus, todèl delyro diagnostika gali būti nepakankama. 
Delyro ir kognityviniu sutrikimu atrankinis 4AT metodas (angl. 4AT - Screening for delirium and cognitive impairment). Ši priemoné sukurta greitam pradiniam delyro ir kognityvinių sutrikimų ịvertinimui. Skirtas vyresniems žmonèms ( $>65 \mathrm{~m}$.), arba tiems, kurie turi žinomų predisponuojančių veiksnių ar būklių. Skaičiuojamas paciento neteisingai atsakytų klausimų skaičius. Pacientui, surinkusiam $\geq 4$ balus, nustatomas tikètinas delyras. Šio metodo pranašumas
- delyrą gali vertinti žmonès, kurie turi tik bazines žinias apie delyrą [20,21].

Sumišimo vertinimo metodas CAM (angl. Confusion assessment method). Ši delyro diagnostikos priemonè yra plačiai aprašyta. CAM remiasi keturiais pagrindiniais delyro bruožais (staigi pradžia ir nepastovi eiga; nedemesingumas; padrikas (dezorganizuotas) mąstymas; pakitęs sąmonès lygis). Delyras nustatomas tuomet, jeigu pacientui pasireiškia

1 lentelè. Delyro atrankos ir diagnostikos skalių palyginimas

Santrumpos: IT - intensyvioji terapija; SPS - skubiosios pagalbos skyriai.

NEECHAM - The Neelon and Champage Confusion Scale; Nu-DESC - Nursing Delirium Screening Scale; DOSS - Delirium observation screening scale; ICDSC - Intensive care delirium screening checklist; PAED - Pediatric Anesthesia Emergence Delirium scale; GAR - Global Attentiveness Rating; 4AT - 4AT-Screening for Delirium and Cognitive Impairment; CAM - Confusion Assessment Method; DSI - Delirium Symptom Interview; CTD - Cognitive test for delirium; DDS - Delirium Detection Score.

\begin{tabular}{|c|c|c|c|c|c|}
\hline $\begin{array}{l}\text { Vertinimo } \\
\text { priemoné }\end{array}$ & $\begin{array}{l}\text { Jautrumas // } \\
\text { specifiškumas }\end{array}$ & Vertintojas & $\begin{array}{l}\text { Vertinimo } \\
\text { trukmé }\end{array}$ & Vertinami parametrai & Paskirtis \\
\hline $\begin{array}{l}\text { NEECHAM } \\
{[12,13]}\end{array}$ & $\begin{array}{l}95-97,2 \% / / \\
78-82,8 \%\end{array}$ & Slaugytojos & $10-15 \mathrm{~min}$. & $\begin{array}{l}9 \text { parametrai: } \\
\text { dèmesingumas, gebejjimas vykdyti nurodymus, orientacija, } \\
\text { išvaizda, kalbėsena, motorika, gyvybinių funkcijų pastovu- } \\
\text { mas, } \mathrm{O}_{2} \text { saturacija, šlapinimosi kontrolè }\end{array}$ & $\begin{array}{l}\text { IT neintubuoti paci- } \\
\text { entai }\end{array}$ \\
\hline $\begin{array}{l}\text { Nu-DESC } \\
{[14,15]}\end{array}$ & $\begin{array}{l}85,7 \% / / \\
86,8 \%\end{array}$ & Slaugytojos & $\begin{array}{l}1-2 \text { min.; } \\
3 \text { kartus per } \\
\text { parą }\end{array}$ & $\begin{array}{l}5 \text { parametrai: } \\
\text { dezorientacija, komunikavimas, elgesys, haliucinacijos, } \\
\text { psichomotorinis sutrikimas }\end{array}$ & $\begin{array}{l}\text { Ivairūs pacientai kas- } \\
\text { dienèje praktikoje; } \\
\text { ypač chirurginio pro- } \\
\text { filio }\end{array}$ \\
\hline $\begin{array}{l}\text { DOSS } \\
{[16,17]}\end{array}$ & $\begin{array}{l}92-99,9 \% / / \\
82-99,5 \%\end{array}$ & Slaugytojos & $\begin{array}{l}2-3 \text { min.; } \\
3 \text { kartus per } \\
\text { parą }\end{array}$ & $\begin{array}{l}8 \text { parametrai: } \\
\text { sąmonè, dèmesingumas, mąstymas, atmintis ir orientacija, } \\
\text { psichomotorinis aktyvumas, miego-būdravimo ciklas, nuo- } \\
\text { taika, suvokimas }\end{array}$ & $\begin{array}{l}\text { Ivairūs pacientai kas- } \\
\text { dienèje praktikoje; la- } \\
\text { biau tinka vyresniems } \\
\text { pacientams }\end{array}$ \\
\hline $\begin{array}{l}\text { ICDSC } \\
{[12,13,18]}\end{array}$ & $\begin{array}{l}96-99 \% / / \\
64-72,4 \%\end{array}$ & $\begin{array}{l}\text { Bet kuris IT } \\
\text { darbuotojas }\end{array}$ & $\begin{array}{l}7-10 \text { min.; } \\
\text { b ù t in a s } \\
\text { stebejjimas } \\
\text { bent } 24 \text { val. }\end{array}$ & $\begin{array}{l}8 \text { parametrai: } \\
\text { sąmonè, dėmesingumas, dezorientacija, haliucinacijos/psi- } \\
\text { chozė, psichomotorinis sujaudinimas/ } \\
\text { slopinimas, kalba ir nuotaika, miego-būdravimo ciklas, } \\
\text { simptomų nepastovumas }\end{array}$ & IT pacientai \\
\hline $\begin{array}{l}\text { PAED } \\
{[19]}\end{array}$ & $\begin{array}{l}64-86 \% / / \\
86 \%\end{array}$ & Gydytojai & 3-5 min. & $\begin{array}{l}5 \text { parametrai: } \\
\text { akių kontakto palaikymas, tikslių veiksmų atlikimas, aplin- } \\
\text { kos suvokimas, nerimastingumas, emocinis sujaudinimas }\end{array}$ & $\begin{array}{l}\text { SPS vaikai ir vaikai po } \\
\text { anestezijos }\end{array}$ \\
\hline GAR & $\begin{array}{l}94 \% / / \\
99 \%\end{array}$ & Gydytojai & $\begin{array}{l}\text { Mažiausiai } \\
2 \text { min. }\end{array}$ & Paciento gebèjimas palaikyti normalų pokalbị & $\begin{array}{l}\text { Labiau tinkama vyres- } \\
\text { niems pacientams }\end{array}$ \\
\hline $\begin{array}{l}\text { AT } \\
{[20,21]}\end{array}$ & $\begin{array}{l}81,5-89,7 \% / / \\
84,1-87,5 \%\end{array}$ & $\begin{array}{l}\text { Apmokytas } \\
\text { medicinos } \\
\text { personalas }\end{array}$ & $1-3$ min. & $\begin{array}{l}\text { Budrumas, dèmesingumas, staigūs pokyčiai, 4AT: amžius, } \\
\text { gimimo data, vieta, einamieji metai }\end{array}$ & $\begin{array}{l}\text { Itvairūs; ypač žmonėms } \\
>65 \mathrm{~m} .\end{array}$ \\
\hline $\begin{array}{l}\text { CAM } \\
{[22-25]}\end{array}$ & $\begin{array}{l}46-100 \% / / \\
63-100 \%\end{array}$ & $\begin{array}{l}\text { Apmokyti } \\
\text { gydytojai }\end{array}$ & 4-5 $\min$. & $\begin{array}{l}9 \text { parametrai: } \\
\text { staigi pradžia, dėmesingumas, mąstymas, sąmonè, dezo- } \\
\text { rientacija, atminties sutrikimai, psichomotoriniai sutrikimai, } \\
\text { miego-būdravimo ciklas, suvokimo sutrikimai }\end{array}$ & $\begin{array}{l}\text { Pagal metodo varinci- } \\
\text { jas: IT, SPS, kt. }\end{array}$ \\
\hline $\begin{array}{l}\text { DSI } \\
{[26]}\end{array}$ & $\begin{array}{l}90 \% / / \\
80 \%\end{array}$ & $\begin{array}{l}\text { Apmokytas- } \\
\text { medicinos } \\
\text { personalas }\end{array}$ & $10-15 \min$. & $\begin{array}{l}7 \text { parametrai: } \\
\text { dezorientacija, sąmonės sutrikimai, miego-būdravimo ciklas, } \\
\text { suvokimas, kalba, psichomotorika, elgesys }\end{array}$ & $\begin{array}{l}\text { Vyresnio amžiaus pa- } \\
\text { cientai }(>65 \mathrm{~m} .]\end{array}$ \\
\hline $\begin{array}{l}\text { CTD } \\
{[27]}\end{array}$ & $\begin{array}{l}100 \% / / \\
95,1 \%\end{array}$ & $\begin{array}{l}\text { Apmokytas } \\
\text { medicinos } \\
\text { personalas }\end{array}$ & $10-15$ min. & $\begin{array}{l}5 \text { parametrai: orientacija, demesingumas, atmintis, suvo- } \\
\text { kimas, budrumas }\end{array}$ & $\begin{array}{l}\text { IT pacientai, ypač in- } \\
\text { tubuoti ar turintys kitų } \\
\text { funkcijų sutrikimų }\end{array}$ \\
\hline $\begin{array}{l}\text { DDS } \\
{[12]}\end{array}$ & $\begin{array}{l}69 \% / / \\
75 \%\end{array}$ & $\begin{array}{l}\text { Apmokytas } \\
\text { medicinos } \\
\text { personalas }\end{array}$ & 3-4 min. & $\begin{array}{l}8 \text { parametrai: } \\
\text { orientacija, susijaudinimas, nerimas, haliucinacijos, prie- } \\
\text { puoliai su traukuliais, paroksizminis prakaitavimas, miego- } \\
\text { būdravimo ciklas, tremoras }\end{array}$ & IT \\
\hline
\end{tabular}


staigios pradžios ir nepastovios eigos nedèmesingumas, lydimas bent vieno iš dviejų kitų simptomų - padriko mąstymo ar pakitusio sąmonès lygio. CAM lengva naudoti, CAM skalė turi įvairių specifinių modifikacijų, leidžiančių šią priemonę taikyti skirtingose situacijose, pavyzdžiui, intensyviosios terapijos skyriuje ir kt. Vertintojai turi būti apmokyti naudotis CAM metodu [22]. Šis metodas validuotas ir išverstas i daugiau nei 20 kalbų. Yra keletas CAM variantų (visi jie remiasi anksčiau minètais pagrindiniais keturiais delyro bruožais):

Ultratrumpasis CAM (UB-CAM) (angl. Ultra-brief CAM). Paciento klausiama tik dviejų klausimų: kokia savaitės diena ir išvardinti mėnesius atbuline tvarka. Jeigu gaunamas pozityvus rezultatas (pozityviu delyro ženklu laikomas neteisingai atsakytas, neatsakytas, nežinomas, kaip atsakyti klausimas), tuomet taikomas kitas žingsnis - 3 minučių diagnostikos CAM (3DCAM).

3 minučiu diagnostikos CAM (3DCAM) (angl. 3-minute diagnostic confusion assessment method). Šis CAM variantas susideda iš klausimų pacientui ir testuotojo objektyviai vertinamų parametrų (pvz., kalbos sklandumas, dėmesingumas ir kt.). Skalès jautrumas 95 proc., specifiškumas 94 proc., trukmè - apie 3 min. [23]. Geras jautrumas (96\%) ir specifiškumas (96\%) stebimas pacientams, turintiems demenciją [24].

Trumpasis CAM (B-CAM) (angl. Brief-CAM). Skalè, naudojama skubiosios pagalbos skyriuose. Vertinimas trunka mažiau kaip 2 minutes, o dèmesys labiausiai kreipiamas ị padriko mąstymo kriterijų.

Intensyviosios terapijos CAM (CAM-ICU) (angl. CAM for the ICU). Adaptuotas stebeti intensyviosios terapijos skyriaus intubuotus pacientus. Vertinant paciento būklę, ji lyginama su būsena, stebèta atvykus ị ITS. Galima vertinti verbaliai negalinčius bendrauti pacientus (pvz., dėmesingumui ịvertinti paciento prašoma suspausti egzaminuotojo ranką išgirdus raidę, kurią pasakè egzaminuotojas). Šis metodas reikalauja naudoti validuotą sąmoningumo ar sedacijos skalę, pvz., RASS. Trunka 2-3min. Bendras jautrumas 95-100 procentų; ventiliuojamiems pacientams jautrumas 92-100 procentų. Bendras specifiškumas $89-93$ procentai, ventiliuojamiems pacientams $88-100$ procentu [25].

Šeimos CAM (FAM-CAM) (angl. Family-CAM). Skirta vyresniems pacientams ir pritaikyta taip, kad klinicistai galètų įvertinti paciento būklę ne tik bendraudami, bet ir telefonu ar el. paštu. Šeimos nariai taip pat gali taikyti šį metodą, tačiau prieš tai turi būti apmokyti. Trunka 5-10 minučių. Jautrumas 88 proc., specifiškumas 98 procentai.

Pediatrinis CAM (pCAM-ICU), skirtas intensyviajai terapijai (angl. Pediatric CAM - intensive care unit). Pritaikytas įvertinti delyrą kritinès būklès pediatriniams pacientams (tinka ir intubuotiems, ir ne). Skale skirta vaikams nuo 5 metų. Trunka mažiau nei 2 min., gali vertinti gydytojai ar slaugytojos. Būtinas RASS įvertinimas ir specialios ASE (angl. Attention screening exam) paveikslèlių kortelès. Jautrumas 83 proc., specifiškumas 99 proc., pozityvi predikcinè vertė 93 proc., negatyvi predikcinè verté 98 procentai.

CAM (psCAM-ICU), skirtas ikimokyklinio amžiaus vaikams (angl. Preschool CAM - intensive care unit). Skirta dar jaunesniems pacientams - nuo 6 mèn. iki 5 metų. Specifiškumas 91 proc., jautrumas 75 proc., negatyvi predikcinè vertė 86 proc., pozityvi predikcinè verte 84 procentai.

Delyro simptomu interviu DSI (ango. Delirium symptom interview). Apie DSI metodą naujos informacijos nedaug; skalè naudojama retai, todèl šio metodo patikimumą ịvertinti yra gana sunku [26].

Kognityvinis delyro testas CTD (angl. Cognitive test for delirium). Skirta ITS, ypač intubuotiems ar turintiems kitokių funkcinių sutrikimų pacientams. Naujos informacijos mažai [27].

Delyro aptikimo balas DDS (angl. Delirium Detection Score). Skalè originaliai kurta vertinti alkoholio nutraukimo sindromą, tačiau ja galima nustatyti delyrą ir jo laipsnị. DDS parode gerą koreliaciją tarp egzaminuotojų, bet tik tuo atveju, jei prieš tai egzaminuotojai buvo apmokyti ja naudotis [12].

\section{Diskusija}

Ar geriausiai ištirtos skalės - geriausias pasirinkimas? Gausiausiai pasaulio literatūroje aprašytos delyro stebėsenos skalès yra NEECHAM, CAM ir Nu-DESC. Manoma, jog NEECHAM metodas labiau tinkamas pacientams, kurie hospitalizuoti terapiniuose ar chirurginio profilio skyriuose, tačiau mažiau tinkamas ITS pacientams, tikètinai dẻl skalèje naudojamų parametrų - gyvybinių funkcijų, deguonies saturacijos, šlapinimosi kontrolès dinamiškumo. Dèl kalbinès paciento raiškos vertinimo, ši skale netinka intubuotiems pacientams [13]. Nepaisant šių trūkumų, NEECHAM pasižymi gebejjimu ịvertinti ne tik delyro faktą, bet ir nustatyti tik pradejusį vystytis delyrą ar jo riziką. Tuo tarpu CAM skalè pasaulinejje literatūroje laikoma aukso standartu dèl savo tikslumo, lengvo taikymo, trumpos vertinimo trukmès; be to, šią skalę gali naudoti ne tik gydytojai, bet ir kiti ligoninès darbuotojai, nors prieš tai būtini skalès taikymo ir interpretavimo mokymai [13]. CAM išsiskiria savo variacijų gausa, kurios leidžia gydytojui pritaikyti skalę ịvairiose situacijose naudojant tuos pačius keturis pagrindinius delyro bruožus: staigią pradžią (banguojančią eigą), dèmesio sutrikimus, padriką mąstymą ir pakitusią sąmonę. CAM naudoti gali bet kuris apmokytas vertintojas; vis dèlto, dèl neteisingo skalès taikymo ir vertintojo nepatyrimo kyla grésmè nepakankamai diagnozuoti delyrą klinikinèje praktikoje $[1,5,6]$.

Nu-DESC metodas nuo NEECHAM ir CAM skiriasi tuo, 
jog reikia pakartotinio paciento būklès vertinimo, o delyro diagnozė remiasi paros matavimų vidutinėmis reikšmėmis. Slaugytojos, su pacientu praleidžiančios daugiau laiko ir dirbdamos pamainomis, turi didesnę tikimybę nustatyti besivystantị delyrą, o tai ypač svarbu stebint sunkios ir greitai besikeičiančios būklès pacientus [27].

Delyro intensyviojoje terapijoje problematika. Intensyvios terapijos skyrių pacientų sąmonès būklè gali būti labai ịvairi; vertinami komoje esantys, turintys kitų stiprių sąmonès ir suvokimo sutrikimų, kenčiantys ar seduoti pacientai, kurių būklę reikia atskirti nuo gretutinių patologijų (pvz., demencija). Dauguma delyro diagnostinių skalių, puikiai vertinančių hiperaktyvų delyrą, nenustato hipoaktyvaus (apsvaigimas, pasyvumas) delyro, kuris ITS yra dažnesnis [12] ir indikuoja blogesnę prognozę [29]. Dèl darbo ITS specifikos, labai svarbu, jog delyro diagnostikos būdai būtų paprasti, juos būtų galima naudoti apeinant verbalinio atsako vertinimą, metodas turi būti suprantamas neturintiems psichiatrinio pasirengimo komandos nariams ir lengvai interpretuojamas. Dažniausiai ITS naudojamos delyro skalès yra CAM-ICU, ICDSC, NEECHAM, Nu-DESC, CTD ir DDS.

CAM-ICU variantas nevertina delyro subtipų, o paciento būklę atspindi tik vertinamuoju laikotarpiu. Dèl šios priežasties specialistai turètų pacientą vertinti kelis kartus per dieną. Naudojant šią metodiką, būtinas bent minimalus kontaktas su pacientu. ICDSC metodas šiuo atveju yra pranašesnis, nes pacientas vertinamas pasyviai. Be to, ICDSC lengva ịtraukti ị kasdienę praktiką, nes ịvertinimui naudojami duomenys, kurie ir taip stebimi IT skyriuose. Kitas ICDSC pliusas yra tas, jog galima îvertinti ir subsindromini delyrą [25], be to, skalè yra jautresnè (99\%), lyginant su CAM-ICU, nors specifiškumas (64\%) yra ženkliai mažesnis. ICDSC, lyginant su CAM-ICU, geriau numato baigtis, tačiau CAM-ICU yra tinkamesnis ventiliuojamiems pacientams, patikimiau atmeta delyro diagnozę, jeigu jo nèra [30,31]. Svarbus ICDSC trūkumas yra sunkus sąmoningumo nustatymas, ypač, jei vertintojas nepatyręs, todèl išlieka didele tikimybè delyro diagnozę nustatyti neteisingai.

DDS skalè išsiskiria tuo, jog vertina ne tokius dažnus delyro bruožus, pavyzdžiui, tremorą ar paroksizminị prakaitavimą. Vis dèlto, kadangi šie simptomai yra ne tokie būdingi delyrui, DDS jautrumas (69\%) yra mažesnis lyginant su kitomis skalèmis, todèl nepatariama naudoti šios skalès paciento sąmonès ir kognityvinès būsenos stebèsenai [32].

Delyro diagnostika senyvo amžiaus pacientams. Dar viena specifinè pacientų grupè yra senyvo amžiaus žmonès. Delyras vyresniems pacientams pasireiškia dažnai - 11-40 proc. hospitalizuotų šios grupès pacientų turi delyrą [33,34], tačiau didelè dalis lieka nediagnozuota dèl sunkios diferencinès diagnostikos su kitomis gretutinèmis patologijomis.
Vyresni pacientai ị ligoninę atvyksta dẻl ịvairių priežasčių, kurios taip pat gali lemti sąmonès, suvokimo ir dėmesio sutrikimus, pavyzdžiui, polifarmacija ir jos nepageidaujami reiškiniai, sunkios infekcijos, kepenų ar inkstų encefalopatija ir kt., todèl pacientą dèl delyro būtina pakartotinai vertinti ir po minètų būklių įtarimo, diagnostikos bei pradèto gydymo. Dažniausios delyrą primenančios būklès yra depresija, psichozè ir demencija [35]. Staigi sąmonès, dèmesio, mąstymo sutrikimų pradžia yra svarbus bruožas, padedantis atskirti šias patologijas nuo delyro. Demencija, su kuria delyrą diferencijuoti reikia dažniausiai, yra apibūdinama kaip lètinè smegenų funkcijos sutrikimo progresija, o delyras yra staigus psichinès būklès pokytis. Šios dvi patologijos dažnai eina kartu, nes preegzistuojantis kognityvinis sutrikimas yra delyro išsivystymo rizikos veiksnys. Nustatyti demenciją padeda IQCODE metodas. Tai klausimynas, kuris padeda įvertinti kognityvinių funkcijų blogejjimą senyvo amžiaus pacientams. Și klausimyną gali taikyti ne tik medicinos personalas, bet ir kiti asmenys, besirūpinantys senu žmogumi. IQCODE susideda iš 26 (sutrumpintame variante - 16) klausimų apie kasdienes situacijas, kurias spręsdamas pacientas turi pasitelkti savo atmintị ir loginị mąstymą. Kiekviena situacija vertinama 10, 5 metų ar kitu testuotojo pasirinktu laikotarpiu. Pacientą galima ịvertinti ir pasyviai, todèl IQCODE galima ịvertinti demenciją ir delyrą turinčius pacientus.

Delyras senyvo amžiaus pacientams vertinamas CAM, 4AT, Nu-DESC, DSI ir GAR metodais. Taikyti šias skales senyvo amžiaus pacientams, ypač turintiems gretutinių psichinių sutrikimų, turètų tik gerai apmokyti ir patirties turintys specialistai dèl sudètingos patologijų diferenciacijos. Siūloma taikyti ne tik nurodytas skales, bet kombinuoti jas su bendro pobūdžio pokalbiu su pacientu [33]. Kitas siūlytinas metodas būtų daugiadisciplininès komandos vertinimas, leidžiantis įvertinti visas senyvo amžiaus paciento būkles, galinčias daryti įtaką delyro diagnostikai.

\section{Išvados}

1. Lietuvoje stebima delyro hipodiagnostikos problema, kurią spręsti būtų galima pasitelkiant validuotas delyro stebėsenos ir diagnostikos skales. Geriausiai ištirti ir plačiausiai pasaulyje taikomi metodai yra NEECHAM, CAM ir Nu-DESC. CAM skalè, kuri laikoma aukso standartu, yra plačiausiai taikoma, aukšto jautrumo ir specifiškumo, tačiau netinkama delyro subtipų vertinimui. Skalę gali naudoti ne tik gydytojai, tačiau prieš tai būtini skalès interpretacijos mokymai. NEECHAM metodo privalumas - delyro išsivystymo rizikos nustatymas, o Nu-DESC pasižymi tuo, jog turi būti taikomas pakartotinai, siekiant ịvertinti delyro dinamiškumą.

2. Intensyviojoje terapijoje patikimiausios delyro ver- 
tinimo skalès yra CAM-ICU ir ICDSC ir DDS. CAM-ICU tinka ventiliuojamiems pacientams ir patikimiau atmeta delyrą, jeigu jo nèra, tačiau negali nustatyti delyro subtipo. ICDSC yra labiau tinkamas visiškai nekontaktuojantiems pacientams ir norint aptikti subsindromini delyrą. DDS teoriškai galètų ịvertinti netipinius delyro simptomus, tačiau apie šios skalès taikymo privalumus šiandieninèje medicinos praktikoje informacijos yra mažai.

3. Senyvo amžiaus žmonių delyrui vertinti gali būti naudojami 4AT, DOSS, DSI, GAR, o dažniausiai - CAM ir Nu-DESC metodai. Nu-DESC gali įvertinti ir hipoaktyvu delyrą, todèl pranašesnis vyresniems pacientams. Papildomai šioje pacientų grupejje siūlytina taikyti IQCODE klausimyną.

4. Apie DSI, CTD, DDS, GAR ir PAED metodų patikimumą ir privalumus naujos informacijos yra nedaug, todél būtų tikslinga toliau tirti šias delyro vertinimo skales.

5. Esant delyro atrankos ir diagnostikos skalių i̇vairovei, išlieka trumpos, greitai ir paprastai pritaikomos, aukšto jautrumo ir specifiškumo, suvienodintos vertinimo skalès, tinkamos įvertinti ne tik delyro buvimo faktą, bet ir jo subtipą, sukūrimo poreikis.

\section{Literatūra}

1. Mattison MLP. Delirium. Ann Intern Med 2020;173(7):ITC49ITC64.

https://doi.org/10.7326/AITC202010060

2. Kennedy M, Helfand BKI, Gou RY, et al. Delirium in older patients with COVID-19 presenting to the Emergency Department. JAMA Netw Open 2020;3(11):e2029540.

https://doi.org/10.1001/jamanetworkopen.2020.29540

3. Milbrandt EB, Deppen S, Harrison PL, et al. Costs associated with delirium in mechanically ventilated patients. Critical Care Medicine 2004;32(4):955-962.

https://doi.org/10.1097/01.CCM.0000119429.16055.92

4. Arumugam S, El-Menyar A, Al-Hassani A, et al. Delirium in the intensive care unit. J Emerg Trauma Shock 2017;10(1):37-46. https://doi.org/10.4103/0974-2700.199520

5. Ely EW, Shintani A, Truman B, et al. Delirium as a predictor of mortality in mechanically ventilated patients in the intensive care unit. JAMA 2004;291(14):1753-1762.

https://doi.org/10.1001/jama.291.14.1753

6. Kakuma R, du Fort GG, Arsenault L, et al. Delirium in older emergency department patients discharged home: effect on survival. J Am Geriatr Soc 2003;51(4):443-450.

https://doi.org/10.1046/j.1532-5415.2003.51151.x

7. Serpytis P, Navickas P, Navickas A, et al. Age- and gender-related peculiarities of patients with delirium in the cardiac intensive care unit. Kardiol Pol 2017;75(10):1041-1050.

https://doi.org/10.5603/KP.a2017.0122

8. Vasilevskis EE, Han JH, Hughes CG, et al. Epidemiology and risk factors for delirium across hospital settings. Best Pract Res Clin Anaesthesiol 2012;26(3):277-287.

https://doi.org/10.1016/j.bpa.2012.07.003

9. Jayaswal AK, Sampath H, Soohinda G, et al. Delirium in medical intensive care units: Incidence, subtypes, risk factors, and outcome. Indian J Psychiatry 2019;61(4):352-358.

https://doi.org/10.4103/psychiatry.IndianJPsychiatry_583_18

10. Battle DE. Diagnostic and statistical manual of mental disorders (DSM). Codas 2013;25(2):191-192.

https://doi.org/10.1590/S2317-17822013000200017

11. Devlin JW, Fong JJ, Howard EP, et al. Assessment of delirium in the intensive care unit: nursing practices and perceptions. Am J Crit Care 2008;17(6):555-565.

https://doi.org/10.4037/ajcc2008.17.6.555

12. Carvalho JPLM, de Almeida ARP, Gusmao-Flores D. Delirium rating scales in critically ill patients: a systematic literature review. Rev Bras Ter Intensiva 2013;25(2):148-154.

https://doi.org/10.5935/0103-507X.20130026

13. Grover S, Kate N. Assessment scales for delirium: A review. World J Psychiatry 2012;2(4):58-70.

https://doi.org/10.5498/wjp.v2.i4.58

14. Gaudreau JD, Gagnon P, Harel F, et al. Fast, systematic, and continuous delirium assessment in hospitalized patients: the nursing delirium screening scale. J Pain Symptom Manage 2005;29(4):368-375.

https://doi.org/10.1016/j.jpainsymman.2004.07.009

15. Hargrave A, Bastiaens J, Bourgeois JA, et al. Validation of a nurse-based delirium-screening tool for hospitalized patients. Psychosomatics 2017;58(6):594-603.

https://doi.org/10.1016/j.psym.2017.05.005

16. Neefjes ECW, van der Vorst MJDL, Boddaert MSA, et al. Accuracy of the Delirium Observational Screening Scale (DOS) as a screening tool for delirium in patients with advanced cancer. BMC Cancer 2019;19(1):160.

https://doi.org/10.1186/s12885-019-5351-8

17. Teale E, Young J, Siddiqi N, et al. Study protocol-investigation of the delirium observation screening scale (DOSS) for the routine detection of delirium in the care home setting: a prospective cohort study. BMJ Open 2016;6(6):e009615.

https://doi.org/10.1136/bmjopen-2015-009615

18. Sessler CN, Gosnell MS, Grap MJ et al. The Richmond agitation-sedation scale: validity and reliability in adult intensive care unit patients. Am J Respir Crit Care Med 2002;166(10):1338-1344.

https://doi.org/10.1164/recm.2107138

19. Simonsen BY, Skovby P, Lisby M. An evaluation of the Danish version of the pediatric anesthesia emergence delirium scale. Acta Anaesthesiol Scand 2020;64(5):613-619.

https://doi.org/10.1111/aas.13543

20. Bellelli G, Morandi A, Davis DH, et al. Validation of the 4AT, a new instrument for rapid delirium screening: a study in 234 
hospitalised older people. Age Ageing 2014;43(4):496-502. https://doi.org/10.1093/ageing/afu021

21. Jeong E, Park J, Lee J. Diagnostic test accuracy of the 4at for delirium detection: a systematic review and meta-analysis. Int J Environ Res Public Health 2020;17(20):7515. https://doi.org/10.3390/ijerph17207515

22. Motyl CM, Ngo L, Zhou W, et al. Comparative accuracy and efficiency of four delirium screening protocols. J Am Geriatr Soc 2020;68(11):2572-2578.

https://doi.org/10.1111/jgs.16711

23. Marcantonio ER, Inouye SK. 3D-CAM. Ann Intern Med 2015;162(7):527-528. https://doi.org/10.7326/L15-5073

24. Marcantonio ER, Ngo LH, O'Connor M, et al. 3D-CAM: derivation and validation of a 3-minute diagnostic interview for CAM-defined delirium: a cross-sectional diagnostic test study. Ann Intern Med 2014;161(8):554-561. https://doi.org/10.7326/M14-0865

25. Kallenbach T, Amado L. Assessment of delirium in the intensive care unit. Southern African Journal of Anaesthesia and Analgesia 2017;23(3):57-63. https://doi.org/10.1080/22201181.2017.1332809

26. Albert MS, Levkoff SE, Reilly C, et al. The Delirium Symptom Interview: An Interview for the Detection of Delirium Symptoms in Hospitalized Patients. Journal of geriatric psychiatry and neurology 1992;5(1):14-21. https://doi.org/10.1177/002383099200500103

27. Rnic K, Dozois DJA. Treatment-relevant assessment in cognitive-behavioral therapy. The Science of Cognitive Behavioral Therapy 2017;19-50. https://doi.org/10.1016/B978-0-12-803457-6.00002-7

28. Brummel NE, Vasilevskis E, Han JH, et al. Implementing delirium screening in the ICU: secrets to success. Critical Care Medicine 2013;41(9):2196-2208.

https://doi.org/10.1097/CCM.0b013e31829a6f1e

29. Robinson TN, Raeburn CD, Tran ZV, et al. Motor subtypes of postoperative delirium in older adults. Arch Surg 2011;146(3):295-300.

https://doi.org/10.1001/archsurg.2011.14

30. Krewulak KD, Rosgen BK, Ely EW, et al. The CAM-ICU-7 and ICDSC as measures of delirium severity in critically ill adult patients. PLoS One 2020;15(11):e0242378.

https://doi.org/10.1371/journal.pone.0242378

31. Chen TJ, Chung YW, Chang HR, et al. Diagnostic accuracy of the CAM-ICU and ICDSC in detecting intensive care unit delirium: a bivariate meta-analysis. Int J Nurs Stud 2021;113:103782.

https://doi.org/10.1016/j.ijnurstu.2020.103782

32. Luetz A, Heymann A, Radtke FM, et al. Different assessment tools for intensive care unit delirium: which score to use? Crit Care Med 2010;38(2):409-418.
https://doi.org/10.1097/CCM.0b013e3181cabb42

33. Marcantonio ER. Delirium in hospitalized older adults. N Engl J Med 2017;377(15):1456-66.

https://doi.org/10.1056/NEJMcp1605501

34. Chin YC, Koh GCH, Tay YK, et al. Underdiagnosis of delirium on admission and prediction of patients who will develop delirium during their inpatient stay: a pilot study. Singapore Med J 2016;57(1):18-21.

https://doi.org/10.11622/smedj.2016007

\section{HYPODIAGNOSTICS OF ORGANIC DELIRIUM: DIAGNOSTIC PERSPECTIVES IN LITHUANIA \\ D. Kersnauskaitė, R. Kirtiklytė, P. Navickas, P. Šerpytis, A. Navickas}

Keywords: delirium, diagnosis, cognitive impairment, scales and methods.

Summary

It is observed that diagnosis of delirium in Lithuania is not sufficient. It could possibly be explained by the lack of an acknowledged diagnostic algorithm that could be applied by doctors or other medical staff. However, there are some standardized diagnostic and screening scales that can help to detect and diagnose delirium.

Aim. To analyze validated screening and diagnostic methods of delirium which are most widely used in clinical practice.

Methods. A review of 11 screening and diagnostic methods was performed; selected methods were compared with each other according to the purpose of the scale, sensitivity, specificity, evaluator, duration of evaluation and parameters which are evaluated on the scale.

Results. Out of 11 selected scales, mostly studied and described are NEECHAM (95-97.2\% sensitivity and 78-82.8\% specificity), $\mathrm{Nu}-\mathrm{DESC}(85.7 \%$ and $86.8 \%)$, and CAM (46-100\% and $63-100 \%)$. Best methods for the intensive care unit are NEECHAM, ICDSC, CAM, CTD, and DDS. NEECHAM and CAM (CAM-ICU modification) and ICDSC are best described. Elderly patients require an appropriate CAM and Nu-DESC scale. Most scales assess attention, orientation, changes in consciousness, expediency of speech and movements. Re-evaluation is required for Nu-DESC, DOSS and ICDSC methods. Most scales, with the exception of ICD and $\mathrm{Nu}$-DESC, are not suitable for the hypoactive form of delirium.

Conclusions. In intensive care unit the most reliable scales for the evaluation of delirium are CAM-ICU, ICDSC and DDS. CAM and $\mathrm{Nu}$-DESC methods and the IQCODE questionnaire are recommended for elderly patients. ICDSC and Nu-DESC methods are best suited for the assessment of hypoactive delirium. However, even with this variety of delirium detection and diagnostic scales, a need to develop a short, quick and easy-to-apply, highly sensitive and specific scale still exists.

Correspondence to: dziugile.kersnauskaite@gmail.com

Gauta 2021-04-22 